\title{
Valoració dels estudiants universitaris sobre la incorporació de la Universitat Autònoma de Barcelona a l'Espai Europeu d'Educació Superior ${ }^{1}$
}

\author{
Marina Elias Andreu \\ Universitat Autònoma de Barcelona. Departament de Sociologia \\ marina.elias@uab.cat
}

Rebut: $10-09-2010$

Acceptat: 28-03-2011

\section{Resum}

Els canvis de metodologia docent que ha comportat el Procés de Bolonya impliquen variacions en l'avaluació continuada, augment dels treballs en grup, reducció de les classes magistrals i un nombre més elevat de pràctiques. Les valoracions dels estudiants en relació amb la introducció dels canvis metodològics del Procés de Bolonya són positives i negatives alhora. Els estudiants veuen amb bons ulls aquests canvis metodològics, perquè poden significar millores en els aprenentatges que adquireixin, però consideren que, tal com s'estan duent a terme en aquesta universitat, ràpidament, sense recursos i amb poca reflexió prèvia, comporten finalment efectes negatius per a ells.

Davant l'alta càrrega de treball que han comportat aquests canvis, els estudiants es converteixen en actors estratègics, atès que duen a terme accions superficials o profundes segons les tasques que els demanen els professors.

Els canvis en la metodologia docent poden produir efectes positius en el procés d'aprenentatge dels estudiants (pertinença, seguretat i necessitats fisiològiques), però fins que els factors de manteniment no arribin a un cert llindar de qualitat, els efectes positius no es visualitzaran.

Paraules clau: estudiants universitaris; Procés de Bolonya; aproximacions a l'aprenentatge; aprenentatge estratègic.

Abstract. University Students' Opinions About the Incorporation of the Autonomous University of Barcelona into the European Higher Education Area.

Modifications in teaching methodology related to the Bologna Process are producing changes in continuous assessment, an increase of team work, a reduction of traditional lectures, and an increase of practical exercises. Student perceptions regarding the introduction of these changes are both positive and negative. Students believe these methodological changes are good in the sense that they may positively contribute to the learning process.

1. A partir de la tesi doctoral L'aprenentatge dels estudiants universitaris en el marc del Procés de Bolonya, Departament de Sociologia de la UAB, març de 2009. 
But they also believe they produce negative outcomes because of how the Bologna Process is being implemented: too fast, without sufficient resources, and lacking prior reflection process. Because of the workload increase that these changes represent, students are behaving more strategically by engaging in more superficial or profound courses of action depending on the tasks required by the professors. Changes in teaching methodology might produce positive effects in the students' learning process, such as social belonging or increase of self-esteem and self fulfilment.

Key words: university students; Bologna Process; approaches to learning; strategic learning.

\author{
Sumari \\ Introducció \\ 4. Discussió de resultats \\ 1. Introducció del Procés de Bolonya \\ 5. Conclusions \\ 2. Estat de la qüestió \\ Referències bibliogràfiques \\ 3. Resultats
}

\title{
Introducció
}

El procés d'aprenentatge dels estudiants universitaris té lloc en un context determinat i en una societat determinada que incideix en el seu desenvolupament. Així, sembla clar que cal analitzar les modificacions que tenen lloc en el món universitari i els canvis socials que es produeixen avui en dia, sobretot aquells que afecten els joves, els quals són un exemple paradigmàtic dels processos de reformulació que succeeixen en la nostra societat. Una societat envoltada de canvis i de paradoxes noves. Canvis en les relacions socials, en l'escala de valors, en les normes socials, en les expectatives vitals i en les trajectòries de vida.

Específicament, en els canvis socials que impacten els joves, hi destaquen maneres noves de viure, de consumir i de relacionar-se que afecten la construcció de la seva identitat. Hi té una incidència destacable la situació actual del mercat de treball, caracteritzat per un empitjorament progressiu de les condicions laborals, la precarietat i la importància creixent del credencialisme. D'altra banda, la universitat actual es caracteritza per la democratització, tant per la diversificació de les bases socials, com per les transformacions en capital cultural, competències i motivacions dels estudiants. Aquesta democratització comporta una diversificació creixent dels perfils dels alumnes universitaris, que es pot veure reflectida en els diferents règims de dedicació a l'estudi i el compromís flexible dels estudiants respecte a la institució. Així, els canvis en els joves universitaris i l'entrada massiva d'alumnes amb perfils, procedències, inquietuds i maneres de viure diferents és la causa que, a la universitat, el col.lectiu d'alumnes cada vegada sigui més heterogeni, amb maneres diferents de comportar-se davant de la institució i amb actituds i expectatives diverses cap als estudis i la universitat (Masjuan, 2004). 


\section{Introducció del Procés de Bolonya}

Per entendre la implementació del context del Procés de Bolonya a la nostra universitat i les característiques específiques que té, cal considerar les reformes que la precedeixen i les diverses normatives i lleis que n'han anat perfilant el caràcter gairebé únic. El Procés de Bolonya ha patit un procés de recontextualizació, en el sentit que les diverses instàncies implicades realitzen un procés d'adaptació de les directives i de les lleis oficials (Troiano et al., 2010). Fins i tot, s'ha utilitzat el Procés de Bolonya com una oportunitat per canviar certs aspectes de la universitat de cada un dels països anant més enllà de les directives europees, com ara, per exemple, la renovació pedagògica duta a terme a Itàlia, Noruega o a Espanya i la reformulació del sistema de govern a Alemanya.

En aquest sentit, en el nostre context universitari, s'hi estan duent a terme reflexions profundes en relació amb el procés d'ensenyament-aprenentatge a la universitat, aspecte que no està recollit explícitament en els documents oficials de la Unió Europea. La comparació de la nostra universitat amb unes altres d'europees ha comportat la impossibilitat d'oblidar que hi ha alguns desajustos entre les metodologies docents i les necessitats dels aprenents, així, s'ha considerat que és una oportunitat l'entrada de l'EEES per iniciar reflexió i una reforma consegüent de les metodologies pedagògiques que s'han usat durant molts anys a la universitat. Bàsicament, es manifesta la necessitat de dur a terme un tipus d'ensenyament que incentivi l'aprenentatge més adequat per als temps actuals, que sigui al llarg de la vida, un aprenentatge actiu per part de l'estudiant que li permeti aprendre d'una manera més constructiva, per potenciar la capacitat d'aprenentatge i equilibrar els coneixements amb l'adquisició d'habilitats. Les bases d'aquesta traducció van ser establertes l'any 2000 pel Projecte Tuning de la universitat de Deusto, i les agències de qualitat, sobretot la catalana, hi tenen un paper destacat. La UAB va endegar la majoria de projectes pilot i va ser una de les pioneres en aquest camp.

És necessari apuntar que aquesta visió del procés d'ensenyament-aprenentatge no és nova, tot i que n'hi ha molts que així ho han volgut fer veure. Les nocions i els conceptes que s'utilitzen actualment en el món universitari entorn de l'aprenentatge actiu, constructiu, per descobriment, i un llarg etcètera, que s'inclouen sota la noció dels crèdits europeus, parteixen de segles enrere. Concretament, la reforma metodològica que acompanya la introducció dels crèdits europeus consisteix a aplicar a la universitat els principis pedagògics dels moviments de renovació escolar que s'iniciaren a Europa i a Espanya des de la segona meitat del segle XIX (Masjuan, 2004; Rué, 2007) i que tingueren manifestacions destacables a Catalunya mitjançant l'escola activa.

\subsection{Els precedents}

El Procés de Bolonya, que parteix de la Declaració de Bolonya de 1999, estableix les bases per crear l'Espai Europeu d'Educació Superior (EEES), pilar fonamental de la construcció de la Unió Europea. S’emmarca en les reformes educatives impulsades, a partir del procés econòmic de globalització, per ins- 
tàncies internacionals com ara el Banc Mundial, l'Organització Mundial del Comerç, l'Organització per a la Cooperació i el Desenvolupament Econòmic i la UNESCO.

En relació amb els precedents propis de l'Estat espanyol, la Llei de reforma univesitaria (LRU-1983) du a terme canvis en la mateixa línia que les reformes europees, amb la idea d'acostar la universitat a les demandes socials (creació dels consells socials, amb l'entrada de la societat a la universitat) i, per tant, a certes lògiques del mercat laboral. També comença a aparèixer la idea de millorar la qualitat de la docència.

La reforma dels plans d'estudi (1990) pretenia ajustar els diferents estudis a l'augment d'alumnes, la diversificació dels seus perfils i les noves demandes socials. Això va implicar que se centrés l'atenció en el desenvolupament científic, la diversificació cultural i els aspectes professionalitzadors.

Tot i els canvis que propugnaven aquestes reformes, les variacions no van ser unànimes ni clares $\mathrm{i}$, en molts casos, no van comportar modificacions substancials.

\subsection{La Declaració de Bolonya}

La Declaració de Bolonya de 1999 va ser firmada per vint-i-nou països (actualment són quaranta-sis), no tots de la Unió Europea. S’hi discutí sobre la necessitat de crear un espai europeu comú sustentat en principis de qualitat, mobilitat, diversitat i competitivitat, amb el 2010 com a fita conjunta de convergència. Hi ha diverses declaracions que han anat definint els punts bàsics del procés:

- Harmonització de les titulacions: mobilitat.

- European Credit Transfer System (ECTS). Crèdit comú de transferència i acumulació, que contempla el treball autònom de l'estudiant i no només les hores de presencialitat a classe. Un crèdit correspon a unes vint-i-cinc a vint-i-set hores de l'estudiant, en total, unes quaranta hores a la setmana de feina.

— Sistema de qualificacions únic i transparent (grau + màster).

\subsection{Introducció a les universitats espanyoles}

En el nostre país, diversos decrets i lleis han anat perfilant l'entrada a l'EEES. La Llei Orgànica d'Universitats (LOU), de 2001, proposa alguns canvis en el sistema de participació i decisió de la comunitat universitària, crea un sistema més centralitzat de reclutament del professorat i incorpora l'avaluació de les universitats creant l'Agència Nacional d'Avaluació de la Qualitat i l'Acreditació (ANECA). Específicament, en la línia de les reformes europees, la LOU procura aconseguir una millora de la qualitat universitària i, per tant, l'acreditació vinculada amb l'Agència per a la Qualitat del Sistema Universitari de Catalunya (AQU) buscant l'europeïtzació i la internacionalització, l'adquisició 
de competències i d'habilitats i l'ensenyament al llarg de la vida. Concretament, a Catalunya, les proves pilot impulsades pel DURSI (Departament d'Universitats, Recerca i Societat de la Informació) pretenien dur a terme canvis en el funcionament de les titulacions i de l'ensenyament sense canviar el pla d'estudis. Finalment, la Llei Orgànica d'Universitats (LOM-LOU), de 2007, es formulà per sanejar deficiències de la LOU i acostar la universitat a la reforma europea. En aquesta nova llei, hi apareix amb força el paper del Consell Social i el Consell d'Estudiants i, explícitament, s'hi menciona la reforma metodològica docent.

\subsection{Valoració dels actors}

Els inicis del pla pilot es van caracteritzar per la voluntat de convèncer el cos de professorat de les universitats. Es va aconseguir que hi hagués un grup important d'ensenyants entusiasta amb la reforma, encara que també n'hi havia un de més escèptic. Actualment, la falta de recursos, les reformulacions dels canvis i la frenada que han dut a terme alguns òrgans de govern respecte a l'entrada del procés, han provocat un qüestionament general de la situació. De totes maneres, encara hi ha un volum important de professorat que considera que, si es fa bé, la reforma pot ser una oportunitat per a la universitat (Masjuan et al., 2007).

Pel que respecta a l'estudiantat, al començament de la introducció dels plans pilot, hi havia poques queixes. Els alumnes anaven assumint els canvis que s'introduïen a la universitat, però, a partir del març de 2008, van començar les mobilitzacions massives. En les reclamacions dels estudiants, s'hi barregen aspectes diversos que es poden separar en dos nivells diferents. A nivell més teòric, els arguments de les mobilitzacions estudiantils es basen en els perills de la privatització, l'elitització i la mercantilització universitària, aspectes que van més enllà del Procés de Bolonya. A un nivell més diari o quotidià, els estudiants es queixen de l'augment de feina, la poca coordinació entre el professorat, la desinformació i la poca participació en les decisions sobre la implementació del pla. Cal apuntar que cada vegada sembla més clar que les mobilitzacions més insistents són dutes a terme per un grup minoritari d'estudiants que, de vegades, no representen la voluntat de la resta.

\section{Estat de la qüestió}

Es parteix de les aportacions sobre les condicions del procés d'ensenyament i aprenentatge d'Elton $(1988,1996)$, Masjuan i Troiano (2009), Troiano (2005), Prescott i Simpson (2004) i Villar (2006), els quals han utilitzat les aportacions de Herzberg (1966) i Maslow en el camp de l'educació superior. Herzberg sustenta que els individus poden motivar-se en relació amb les tasques que realitzen i poden sentir-se insatisfets si no s'acompleixen certs criteris en el context en què es realitza la tasca. Aquesta visió es complementa amb l'aportació de Maslow respecte al fet que els individus necessiten satisfer les necessitats bàsiques abans de voler satisfer les superiors. 
Aquests necessitats bàsiques són els factors higiènics o de manteniment ${ }^{2}$, tenen a veure amb la percepció de la qualitat de les condicions físiques $\mathrm{i}$ ambientals i influeixen en la desmotivació, encara que en si mateixes no produeixen satisfacció. És necessari controlar aquests factors de manteniment per tal de no desmotivar els individus, que no es motiven per la tasca fins que els factors de manteniment no estan controlats, fins que no arriben a un cert llindar de qualitat. Però no n'hi ha prou que estiguin satisfets per aconseguir la motivació, de manera que també és necessari que hi hagi un cert interès intrínsec $\mathrm{i}$ un encoratjament personal.

Els factors motivacionals són els que permeten desenvolupar la motivació de l'individu i, per tant, el progrés que realitza. Tot i els beneficis, l'absència dels motivadors també pot comportar insatisfacció. A la figura 1 , s'hi poden veure diferents tipus de factors de manteniment i motivadors de l'aprenentatge.

Com es pot comprovar a l'esquema, els aspectes de seguretat i les necessitats fisiològiques són els factors de manteniment, que, necessàriament, han de ser valorats positivament per tal que els estudiants sentin la necessitat de satisfer les necessitats superiors. Els factors motivadors són la pertinença, l'autoestima i l'autorealització, elements que, si són ben valorats, poden ajudar a augmentar la motivació i l'aprenentatge dels estudiants universitaris. Tot i que la teoria de Herzberg ha estat utilitzada per un nombre reduït d'investigadors, fent una revisió dels estudis realitzats i dels resultats, es pot comprovar que aquest model pot ser de gran utilitat per analitzar els aspectes que dificulten o que promouen l'aprenentatge. Cal ser conscient que no només s'ha de tenir en compte la complexitat que comporta la gran quantitat de factors de manteniment que es podrien arribar a identificar, sinó que el mateix Elton (1996) reconeix que és molt difícil concloure si un factor és objectivament considerat de manteniment o motivador.

En l'àmbit universitari, els factors de manteniment serien la bona organització i el bon funcionament del sistema, com ara els horaris o la informació, i els motivadors farien referència a la implicació emocional i intel.lectual dels estudiants (Masjuan, 2005). De la mateixa manera, es podria incloure la percepció dels alumnes sobre la situació del mercat laboral. Una percepció negativa de la seva inserció en el mercat laboral pot propiciar que els estudiants decideixin abandonar la carrera o bé continuar els seus estudis i acceptar sacrificis en el mercat de treball, com ara, per exemple, fer feines o estar en nivells laborals que no corresponen als seus estudis (Troiano, 2005).

Per tant, els alumnes no s'interessaran ni es motivaran per aprendre i aprofundir en la matèria si prèviament no saben què es el que han de fer per aprovar. De la mateixa manera, a l'hora d'iniciar un canvi, és important reduir prèviament els elements que afecten negativament la percepció del context per part dels estudiants. Si no es neutralitzen els elements que desagraden als alumnes, serà molt costós que valorin els efectes positius de l'ensenyament.

2. A partir d'aquest moment, s'usarà l'expressió factors de manteniment. 
Figura 1. Jerarquia de les necessitats dels estudiants

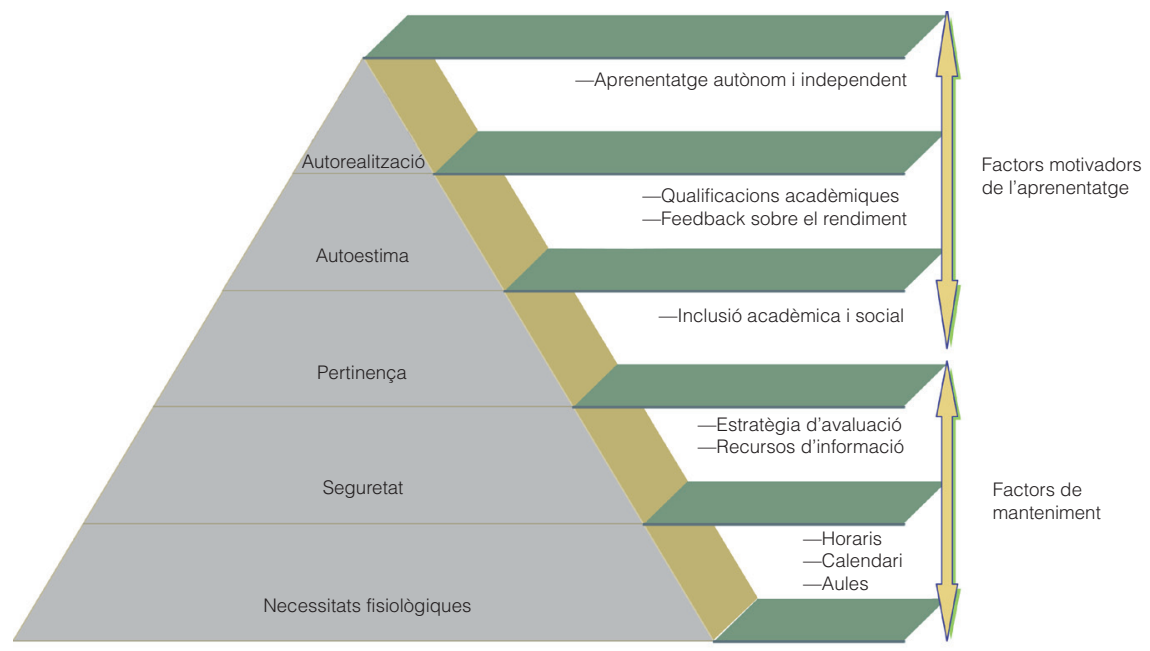

Font: Villar i Font (2007).

\subsection{Aspectes que han canviat a partir de la introducció del Procés de Bolonya als plans pilot de la Universitat Autònoma de Barcelona}

A partir de la introducció dels plans pilot de Bolonya i de les reformulacions docents que han comportat els elements que han provocat més canvis i han suscitat opinions recurrents, $i$ en part contradictòries, per part dels estudiants relacionades amb el seu aprenentatge, són dues. En primer lloc, la introducció o la consolidació de l'avaluació continuada (inclosa en les estratègies d'avaluació de l'ítem de seguretat de la figura 1) i, en segon lloc, els treballs en grup, aquest últim amb efectes en la integració dels estudiants a la institució (fins i tot en els aspectes d'inclusió acadèmica i social de l'ítem de pertinença de la figura 1). A continuació, s'aborden aquests dos aspectes específicament.

\subsubsection{Avaluació continuada}

Més enllà del tipus de docència duta a terme pel professorat, l'avaluació representa un dels aspectes més importants en el procés d'ensenyament- aprenentatge, atès que els estudiants estan altament influïts per l'avaluació que es fa (Masjuan et al., 2009). Així, un canvi concret que s’hi realitzi, per ínfim que pugui semblar, pot tenir conseqüències importants en la manera com els estudiants s'aproximin al seu aprenentatge. Contràriament, si es canvien elements del procés docent o dels continguts i no es tenen en compte els canvis pertinents en l'avaluació, és altament probable que no s'aconsegueixin els canvis desitjats en els estudiants. Així doncs, l'avaluació és un element bàsic en l'aprenentatge dels estudiants universitaris. És necessari, bàsicament, que aquesta sigui explícita i que els estudiants comprenguin què és el que s'espera d'ells (Elton, 1988, 
1996). Aquest és l'aspecte que s'ha analitzat més a fons, justament perquè els efectes dels canvis en l'avaluació tampoc no presenten cap patró uniforme en tots els estudiants.

\subsubsection{Treball en grup}

S'han de destacar les aportacions de diversos autors, bàsicament americans, que han incidit en el pes dels contactes entre els diferents membres de la institució, especialment dels iguals, perquè s'hi integrin.

Les aportacions més interessants parteixen de les teories d'Astin (1984), Tinto $(1998,2000)$ i Weidman (1989). Aquestes teories mostren que la participació activa per part dels estudiants en una varietat d'activitats acadèmiques i socials millora el seu desenvolupament intel-lectual i l'aprenentatge. Així, les relacions a la facultat (fer un bon ensenyament, amb el creixement de l'estudiant tant fora de l'aula com dins) i amb l'entorn del grup classe (freqüència amb la qual els estudiants gaudeixen de les classes, expressen les seves opinions i s'estimulen pel material donat) estan associades amb el creixement intel.lectual (Volkwein et al., 1986). L'aportació de Weidman (1989) rau en la importància de les experiències no universitàries, com ara la socialització familiar i el grup de referència fora de la universitat (Ethington, 2000).

La revisió més integradora de les diverses teories és de Braxton i Hirschy (Villar, 2006), ja que han redefinit el concepte d'integració social, mantenen que aquesta es produeix per les experiències de relació dels estudiants amb els altres membres de la universitat i sustenten que els estudiants se senten integrats si veuen que hi ha congruència d'objectius, visions i normes amb la cultura acadèmica $\mathrm{i}$ amb les pràctiques realitzades per assolir-los.

Les aportacions que s'acaben de citar es poden relacionar amb les teories sobre la socialització universitària. La noció d'integració sustenta implícitament que els estudiants pateixen un procés d'adaptació a la universitat. Així, el procés de socialització contribueix a anar reduint aquest xoc inicial que pateixen els estudiants quan entren a la universitat. El contacte amb els diversos membres de la institució provoca una reducció d'aquest xoc inicial i que l'estudiant es vagi integrant a la universitat. En aquest sentit, es produeix el reconeixement i l'adequació a les normes implícites de la institució ${ }^{3}$, considerades com el conjunt de coneixements, habilitats, actituds i valors que s'adquireix gràcies a les interaccions amb els altres, però que no arriba a fer-se explícit. La integració completa de l'estudiant a la universitat es produeix quan coneix i sap adaptar-se a aquestes normes (Villar i Font, 2007).

En aquest sentit, la identitat dels estudiants es construeix a partir del contacte amb els altres membres de la comunitat universitària i sobretot amb els iguals. Al mateix temps, això comporta efectes en la motivació i l'acció (Hu i Kuh, 2002).

En aquest punt, és útil la separació de Merton (1964) entre el grup de referència $i$ el de pertinença. Es considera que l'individu o el grup de referència

3. Anomenat de vegades currículum ocult. 
és aquell que es pren com a model i del qual es volen adoptar les normes. És un grup significatiu per les actituds i els comportaments propis. Els grups de referència tenen un doble paper: ajuden l'individu a accedir al grup i li faciliten la integració a aquest un cop n'és membre. D’aquesta manera, els grups de referència tenen una doble funció (Botella et al., 1997): una de normativa, en el sentit que els membres del grup comparteixen valors i normes i funciona a través de recompenses o de càstigs, i una de comparació, on l'individu es compara amb el grup i apareixen efectes de privació relativa.

El grup de pertinença (al qual es pertany) pot ser el mateix que el de referència, tot i que aquest últim es pot tractar d'un col-lectiu extern a l'individu. En aquest sentit, un grup de professors o el cos professional futur pot ser un grup de referència per a equips d'estudiants.

La clau per a l'èxit dels estudiants universitaris són les xarxes socials àmplies on s'integren i el nivell de pertinença i d'integració en l'entorn cultural dominant de la universitat. El capital social apareix realment quan els individus inverteixen temps i esforç en activitats de transformació o transacció per augmentar el seu benestar en el futur. El que el diferencia d'altres capitals és, bàsicament, que el social no només beneficia les fites individuals, sinó també les col-lectives i que, quan es crea, acaba beneficiant tots els membres de l'estructura. D'aquesta manera, ajuda els individus a resoldre els problemes de l'acció col-lectiva, i la confiança és un dels beneficis importants del capital social (Croll, 2004).

\section{Resultats}

\subsection{Obtenció de dades}

Les dades s'obtingueren de dues fonts fonamentals. Pel que fa als estudiants, es van recollir els resultats d'una enquesta contestada per alumnes de les catorze titulacions que començaren el pla pilot als cursos 2004-2005 i 2005-2006 de la UAB, com també de vint-i-quatre entrevistes en profunditat dutes a terme a alumnes de tres d'aquestes titulacions pilot: Ciències Polítiques i de l'Administració, Magisteri en Educació Infantil i Enginyeria Informàtica. En relació amb el professorat, es realitzà una entrevista als coordinadors de titulació de cada una de les tres titulacions estudiades en profunditat i es recolliren i s'analitzà documentació diversa en relació amb la implementació del Procés de Bolonya.

A continuació, es presenten els resultats centrats en la valoració dels estudiants. El qüestionari permet entreveure una panoràmica general de la valoració global dels alumnes sobre diversos aspectes dels seus estudis, de la qualitat dels serveis, de la dedicació a l'estudi i de la introducció del pla pilot ${ }^{4}$. Les entrevistes als estudiants ajuden a entendre els resultats quantitatius i introdueixen aportacions

4. Els resultats del qüestionari passat als estudiants es poden trobar als informes realitzats (www.uab.es/gret) i en un article publicat a la Revista Complutense de Educación (Masjuan et al., 2009). 
Taula 1. Qüestionaris recollits i proporció de la mostra

\begin{tabular}{|c|c|c|c|c|c|c|}
\hline \multirow[b]{2}{*}{ Titulació } & \multicolumn{3}{|c|}{ Qüestionaris recollits } & \multirow{2}{*}{$\begin{array}{c}\% \\
2 n\end{array}$} & \multicolumn{2}{|c|}{ Mostra } \\
\hline & $2 n$ & $3 r$ & Total & & $3 r$ & Total \\
\hline Humanitats & 16 & 32 & 48 & 21,3 & 33,3 & 28,1 \\
\hline Traducció i Interpretació & 67 & 34 & 101 & 32,8 & 20,6 & 27,4 \\
\hline Pedagogia & 32 & 34 & 66 & 23,8 & 49,3 & 32,5 \\
\hline Educació Infantil & 58 & & 58 & 38,7 & & 38,7 \\
\hline Educació Primària & 61 & & 61 & 52,5 & & 52,5 \\
\hline Logopèdia & 30 & & 30 & 39,0 & & 39,0 \\
\hline Publicitat & 34 & 46 & 80 & 43,0 & 52,3 & 47,9 \\
\hline Ciències Polítiques & 23 & 21 & 44 & 20,4 & 21,2 & 21,0 \\
\hline Sociologia & 27 & 22 & 49 & 40,3 & 31,4 & 35,0 \\
\hline Geografia & 9 & 7 & 16 & 34,6 & 17,9 & 24,6 \\
\hline Física & 17 & 13 & 30 & 20,7 & 27,1 & 23,1 \\
\hline Matemàtiques & 12 & 15 & 27 & 32,4 & 31,3 & 31,8 \\
\hline Enginyeria Informàtica & 47 & 93 & 140 & 31,3 & 52,5 & 42,8 \\
\hline Veterinària & 100 & 57 & 157 & 39,2 & 38,0 & 38,8 \\
\hline Total & 533 & 374 & 907 & 34,0 & 35,6 & 34,7 \\
\hline
\end{tabular}

Font: Elaboració pròpia.

ben interessants. Així, els resultats de les entrevistes ajuden a explicar les relacions entre variables que dóna l'anàlisi de les respostes dels qüestionaris, a triangular les dades i a intentar entreveure'n possibles mecanismes d'explicació. Les entrevistes als coordinadors i l'anàlisi de la documentació no es presenta explícitament, sinó que ajuda a perfilar i a comprendre les aportacions dels estudiants.

\subsection{El qüestionari a estudiants}

El qüestionari fou emplenat durant el mes d'abril de 2007 per part de 907 estudiants assistents a classe de segon i tercer curs de les catorze titulacions (la proporció de la mostra es pot veure a la taula 1 ). La realització del qüestionari fou pilotada pel Grup de Recerca en Educació i Treball del Departament de Sociologia de la UAB, encara que totes les preguntes incloses en el qüestionari van ser consensuades pels coordinadors de les titulacions pilot, per un representat de l'IDES i pels dos vicerectorats implicats, el Vicerectorat d'Estudiants i Cultura i el Vicerectorat d'Estudis i Qualitat ${ }^{5}$.

El qüestionari recollia aspectes diversos relacionats amb la valoració dels estudiants sobre les hores de dedicació als estudis, el tipus de docència $\mathrm{i}$ l'avaluació duta a terme pel professorat, els serveis de la facultat i la introducció del Pla de Bolonya.

5. Els dos vicerectorats de la UAB van encarregar al GRET que passés el qüestionari i que n'explotés les dades. 
Taula 2. Valoració, per part dels estudiants, de diversos recursos de la universitat

\begin{tabular}{lcc}
\hline Ítem & $\begin{array}{c}\text { Bo i molt bo } \\
\text { (en \%) }\end{array}$ & $\begin{array}{c}\text { Variació } \\
\text { de les titulacions }\end{array}$ \\
\hline Adequació de biblioteques a les necessitats actuals & 75 & 0,25 \\
Qualitat dels serveis informàtics & 70 & 0,18 \\
Qualitat dels laboratoris & 60 & 0,23 \\
Nombre d'alumnes per classe & 58 & 0,33 \\
Utilitat de les guies dels estudiants & 56 & 0,28 \\
L'adequació de les aules & 49 & 0,26 \\
Qualitat de les pràctiques en entitats externes & 49 & 0,23 \\
El Servei de Llengües & 47 & 0,10 \\
La qualitat de les sales d'estudi & 44 & 0,25 \\
\hline
\end{tabular}

Font: Elaboració pròpia.

A continuació, presentem un resum d'aquests resultats quantitatius obtinguts del qüestionari. Totes les taules que s'hi mostren estan referides a preguntes amb respostes de quatre categories i també hi ha la suma de les categories «Bo i molt bo» de cada una de les preguntes.

En general, s'hi constata una valoració negativa en la majoria dels aspectes, ja que la suma de les dues categories positives («Bo i molt bo») no acostuma a superar el $50 \%$ de les respostes dels estudiants. Com es pot observar a la taula 2, les valoracions més positives són les referides als recursos de la universitat. Les valoracions dels estudiants en relació amb la introducció dels plans pilot són més negatives. Una bona mostra la constitueix la taula 3, on destaquen negativament la valoració de la informació que han anat rebent els estudiants sobre Bolonya i la participació en les decisions del pla pilot.

Incorporació al Procés de Bolonya ${ }^{6}$

- La meitat dels estudiants (49\%) es considera informada i l'altra meitat, no.

- Pràcticament la totalitat (98\%) dels estudiants considera que el Procés de Bolonya ha suposat un canvi de metodologia.

- Una tercera part (31\%) valora el canvi positivament («Molt» $\mathrm{i}$ «Bas$\left.\tan )^{\prime}\right)$.

- Una tercera part dels estudiants considera que el Procés de Bolonya s'està implementant bé a la universitat.

- Els tres aspectes que més citen els estudiants que contesten la pregunta oberta $(N=531)$ com a raons positives respecte al pla pilot són: avaluació continuada (54\%), enfocament pràctic (22\%) i millora de l'aprenentatge (12\%).

- Els tres aspectes que més citen els estudiants que contesten la pregunta oberta $(N=666)$ com a raons negatives del pla pilot són: càrrega de feina excessiva (54\%), pla mal planificat $(26 \%)$ i sistema d'avaluació $(23 \%)$.

6. La variació entre titulacions en aquestes preguntes és moderada, no supera el 0,25. 
Taula 3. Valoració dels estudiants dels canvis a partir del Procés de Bolonya.

\begin{tabular}{lcc}
\hline Ítem & $\begin{array}{c}\text { Bo i molt bo } \\
\text { (en \%) }\end{array}$ & $\begin{array}{c}\text { Variació } \\
\text { de les titulacions }\end{array}$ \\
\hline La qualitat amb què es fan les pràctiques & 52 & 0,26 \\
La relació entre estudiants i professors & 51 & 0,18 \\
L'ajuda, el tracte, els consells del professorat & 49 & 0,16 \\
La formació en competències transversals & 49 & 0,18 \\
La qualitat de les classes i els seminaris & 47 & 0,18 \\
Les metodologies que et permeten participar & 46 & 0,12 \\
$\quad$ en una activitat concreta & & \\
La utilització que fa el professorat dels mètodes & 40 & 0,13 \\
actius & 37 & 0,15 \\
La informació que es dóna sobre l'avaluació & 36 & 0,23 \\
El sistema més freqüent d'avaluació & 35 & 0,17 \\
La relació entre la teoria i l'aplicació professional & 34 & 0,15 \\
L'adaptació dels alumnes a la metodologia activa & 32 & 0,19 \\
L'ajust entre els objectius dels cursos i l'avaluació & 32 & 0,10 \\
Les possibilitats de treballar els temes preferits & & \\
L'horari, tant de les assignatures teòriques com & 27 & 0,26 \\
de les pràctiques & 27 & 0,26 \\
La relació entre les hores de teoria i les de pràctica & 26 & 0,26 \\
La coordinació entre assignatures i treballs demanats & 26 & 0,25 \\
El volum de feina que et demanen durant el curs & 17 & \\
La informació dels canvis docents relacionats & & 0,10 \\
$\quad$ amb Bolonya & 12 & 0,12 \\
\hline La participació en les decisions del pla pilot & 6 &
\end{tabular}

Font: Elaboració pròpia.

\subsection{Entrevistes a estudiants}

Es van dur a terme vint-i-quatre entrevistes semiestructurades ${ }^{7}$ a estudiants de les tres titulacions pilot analitzades en profunditat: Ciències Polítiques, Magisteri en Educació Infantil i Enginyeria Informàtica. Els estudiants entrevistats eren de perfils diversos i se'n va mantenir la proporcionalitat segons el sexe i les motivacions d'entrada a la carrera. Les entrevistes foren fetes majoritàriament a estudiants de segon curs i es van realitzar durant els mesos de març i abril de 2008.

En les entrevistes, es preguntava als estudiants sobre diversos aspectes de la seva vida a la universitat, per quin motiu s'havien matriculat en aquella carrera, la seva procedència social i acadèmica, les relacions entre els companys de classe, com s'aproximaven a les assignatures per estudiar i, finalment, es van

7. Entrevistes gravades, transcrites i analitzades a través del programa Atlas-ti. 
Taula 4. Valoració de com ha ajudat als estudiants el Procés de Bolonya en els aspectes següents

\begin{tabular}{lcc}
\hline Ítem & $\begin{array}{c}\text { Bo i molt bo } \\
\text { (en \%) }\end{array}$ & $\begin{array}{c}\text { Variació } \\
\text { de les titulacions }\end{array}$ \\
\hline $\begin{array}{l}\text { Treballar en grup de manera eficient } \\
\begin{array}{l}\text { Desenvolupament personal } \\
\quad(\text { autonomia, esperit crític) }\end{array}\end{array}$ & 58 & 0,23 \\
$\begin{array}{l}\text { Expressar les idees amb claredat per escrit } \\
\text { Expressar les idees amb claredat oralment }\end{array}$ & 48 & 0,13 \\
$\begin{array}{l}\text { Professionalitat (habilitats d'aplicació a la pràctica } \\
\text { dels coneixements) }\end{array}$ & 41 & 0,15 \\
$\begin{array}{l}\text { Tècniques d'estudi i organització del treball } \\
\text { Coneixement i domini de les matèries del pla } \\
\quad \text { d'estudis }\end{array}$ & 37 & 0,19 \\
Coneixement de l'anglès & 30 & 0,11 \\
\hline
\end{tabular}

Font: Elaboració pròpia.

fer preguntes referides a l'entrada del pla pilot en la seva titulació i la valoració que en feien en relació amb els canvis docents.

\subsubsection{Avaluació continuada}

L'aportació de les entrevistes ajudaren a entendre, per exemple, la paradoxa observada en els resultats quantitatius respecte a l'avaluació continuada. En el resultat de la pregunta oberta sobre els aspectes positius i negatius del pla pilot, s'hi observa, alhora, una valoració positiva de l'avaluació continuada i valoracions negatives relacionades amb el mateix aspecte. A través de les entrevistes, es constata que l'avaluació continuada suscita tant valoracions positives com negatives, fins i tot explicitades per un mateix estudiant. L'aspecte positiu, majoritàriament, s'esmenta pel fet d'obligar els alumnes a treballar dia rere dia, i del negatiu es remarca l'excés, en nombre i freqüència, de les proves avaluatives. Aquesta consideració es veu incrementada per la sensació de falta de coordinació entre assignatures.

En el vessant dels aspectes negatius, s'hi detecta un augment important del nombre i la frequiència de les proves, la qual cosa és considerada, per part de tots els estudiants entrevistats, un excés de demandes del professorat, un excés en nombre i freqüència de les proves avaluatives que minva la qualitat dels aprenentatges, perquè als alumnes els manca temps per dedicar-se a aprofundir les matèries. A la taula 5 , s'hi presenten, de forma sintètica, els resultats obtinguts a partir de l'anàlisi de les entrevistes realitzades respecte a l'avaluació continuada.

Aquesta és una paradoxa constant en totes les anàlisis de la introducció del Procés de Bolonya en aquesta universitat (Unitat d'Assessorament Psicopedagògic, 2007), que s'ha pogut comprovar a través de les entrevistes realitzades als estudiants, els quals han entès que la introducció del Procés de Bolonya es basa 
Taula 5. Valoracions dels estudiants entrevistats de l'avaluació continuada

\begin{tabular}{ll}
\hline Aspectes positius & Aspectes negatius \\
\hline Augment i millora dels aprenentatges. & Minva de la qualitat dels aprenentatges. \\
Facilitat per superar assignatures. & Poc reconeixement del treball continuat \\
Millora de les notes. & i poca correspondència de l'esforç invertit \\
en la nota. & Rebaixa dels continguts i del nivell \\
& d'exigència de les matèries. \\
& Manca de temps per aprofundir \\
& les matèries. \\
& Fragmentació dels continguts i pèrdua \\
& de la coherència de l'assignatura. \\
& Augment de l'abandó d'assignatures \\
& (augment de no presentats). \\
& Pràctiques sense integració clara \\
amb l'assignatura. & Sensació d'estrès, cansament físic \\
& i psicològic. \\
\end{tabular}

Font: Elaboració pròpia.

en el seu esforç constant, que serà valorat a través de l'avaluació continuada. Valoren molt positivament aquest nou tipus d'avaluació, perquè els ajuda a estudiar, a aprendre i a ser constants en els seus estudis, alhora que els permet tenir més facilitats per aprovar, treure més bona nota i no haver d'estudiar gaire intensament per als exàmens finals. La qüestió és que consideren que, amb el sistema d'avaluació continuada, s'haurien d'eliminar els exàmens finals o que aquests haurien de suposar molt poc en la seva nota final. Alguns professors segueixen el sistema d'avaluació contínua demanant diverses entregues de feina al llarg del curs, però no han eliminat l'examen final o aquest compta molt en la nota de l'assignatura. Per això, molts estudiants consideren que aquests professors no han entès bé els canvis que demana el Pla de Bolonya, no apliquen bé el sistema d'avaluació, creuen que s'haurien d'eliminar els exàmens de final de curs o, com a mínim, haurien de comptar un petit percentatge en la nota final de l'assignatura. És per aquesta doble consideració que apareix la paradoxa de la valoració positiva de l'avaluació continuada i la valoració negativa del sistema d'avaluació, és a dir, els estudiants valoren positivament l'avaluació continuada, però no tal com s'està implementant.

A continuació, presentem les citacions més representatives de les entrevistes realitzades als alumnes respecte a aquesta qüestió.

Jo crec que hi ha massa esforç perquè després la nota final depengui molt d'un examen a final de curs, moltes assignatures és un 40 les pràctiques i un 60 l'examen final i, és clar, tu has estat, no sé, per fer un treball tres setmanes, t'has hagut de quedar a casa cada dia, aixecar-te d'hora, anar a dormir tard, 
perquè després aprovis el treballs i suspenguis l'examen i diguin «Ui, adéu, al setembre ens veurem» $\mathrm{i}$ al juny que hi hagi un examen final també. (Estudiant de Ciències Polítiques 7)

No són conscients que no només ho fan ells, sinó que també ho fan tots i llavors, a la que s'ajunta tot, hi ha un volum de feina que ells no són conscients, perquè, és clar, si només fessis una assignatura, o tres assignatures, però si en fas set, [...] crec que s’han de coordinar més, parlar més, saber cadascú com fa les coses. No sé, això és una de les coses que se'ls està demanant molt i no en fan gaire cas. Suposo que tots treballen com a ells els agrada i tal i ells fan la seva assignatura $\mathrm{i}$ ja està. (Estudiant de Ciències Polítiques 4)

Un bon grapat de vegades, l'avaluació continuada es relaciona amb una reducció de les classes presencials dutes a terme pel professorat. Aquest procés també suscita valoracions positives i negatives. En el vessant positiu, s'hi veu l'oportunitat d'augmentar l'autonomia dels estudiants al llarg del seu procés d'aprenentatge, però, al mateix temps, el fet que els estudiants tinguin avaluació continuada en moltes assignatures incideix en la percepció que sempre han d'estar pendents dels lliuraments que han de realitzar, i això provoca una sensació de reducció del grau d'autonomia.

Segons aquests estudiants entrevistats, tots els efectes positius que podria comportar l'avaluació continuada respecte al seu aprenentatge, tal com s'ha implantat, amb demandes de feina molt freqüents, els efectes són majoritàriament perjudicials. Fins i tot, n'hi ha alguns que comenten que l'avaluació continuada pot suposar la necessitat de complir amb els lliuraments dels treballs i provocar una disminució dels aprenentatges, ja que no poden dedicar el temps necessari a cadascun.

Davant d'aquesta situació, els estudiants duen a terme estratègies diverses per minvar la sensació de càrrega de feina, com ara reduir l'assistència a les classes en aquelles assignatures que són prescindibles o de les quals poden demanar els apunts (sobretot entre els alumnes que compaginen estudis amb feina). Una altra estratègia consisteix a prioritzar les entregues dels exercicis o dels treballs que compten més en la nota final de l'assignatura o en aquelles assignatures que consideren necessari tenir una bona nota. En general, els alumnes són força estratègics, duen a terme accions diverses per reduir la sensació de càrrega de feina i acostumen a combinar accions diverses segons les tasques que demana el professorat.

Es detecta que, a partir de la implementació dels plans pilot, s'ha produït un augment dels no presentats, ja que els estudiants constaten que no poden dur a terme tots els treballs que se'ls demanen en totes les assignatures i decideixen deixar-ne algunes. De la mateixa manera, es detecta un enuig creixent en els alumnes, sensació que sembla que té tant a veure amb un discurs compartit en contra del Pla de Bolonya com amb una dificultat real diària de dur a terme tota la feina que se'ls demana que facin.

\subsubsection{Treballs en grup}

Els treballs en grup realitzats pels estudiants és un altre dels aspectes que ha augmentat de manera significativa en totes les titulacions emmarcades en el 
pla pilot. Amb l'objectiu d'incentivar el contacte entre els companys i incidir en les competències transversals relacionades amb la feina col-lectiva, cada una de les assignatures demana als seus alumnes que, com a mínim, duguin a terme un treball en grup al llarg del curs.

A través de les aportacions de les entrevistes, es mostra com els estudiants, amb l'afany de treure una bona nota en els treballs en grup (tant se val que sigui un aprovat com un excel.lent, segons les expectatives de cadascú), cerquen un grup estable de companys que s'impliquin en els estudis en el mateix grau, aproximadament, que ells. Així, els alumnes prioritzen els companys més eficients per sobre de l'amistat i saben distingir perfectament un amic per sortir un cap de setmana o anar al bar, d'un company per formar un grup de treball. En aquest sentit, inverteixen en capital social, ja que duen a terme accions per extreure'n un benefici propi.

En aquest sentit, les relacions que s'estableixen entre els companys del treball en grup són d'igualtat. Això no vol dir pas que hagin de ser equitatives, sinó que impliquen més aviat cooperació, és a dir, avui per a tu, demà per a mi. Un retorn just però no necessàriament proporcional. És un sistema de cooperació racional egoista a llarg termini, perquè els individus col-laboren per extreure'n un benefici comú, una recompensa, que, en aquest cas, seria la nota del treball. D’aquesta manera, també es produeix certa pressió de grup perquè tots els estudiants duguin a terme un mínim de feina.

En general, les conseqüències del treball en grup són bàsicament positives si l'alumne és capaç de trobar un equip estable que treballi de manera eficient. Si és així, es produeix un cercle virtuós, ja que la confiança que s'estableix entre els membres de l'equip incrementa l'ajuda mútua amb altres aspectes de la vida universitària i augmenten les xarxes de relació. Evidentment, també es pot produir un cercle viciós quan un estudiant no troba companys eficients, atès que això comporta el risc de no aconseguir dur a terme els treballs a temps o de forma correcta. Aquesta situació tant pot ser provocada perquè al grup hi ha un free rider, un individu que no hi aporta l'esforç que se li requereix i s'aprofita de la feina i els resultats (la nota) dels altres, o perquè un estudiant, tot i saber que els amics no són treballadors, no és capaç de separar l'amistat de la feina i crea un grup de treball d'amics, però no eficient.

Una altra cosa és si els equips són realment cooperatius o si juxtaposen la feina de cada un dels membres. Gràcies a les entrevistes, s'ha detectat que la majoria dels estudiants prefereixen establir grups cooperatius, perquè saben que, d'aquesta manera, tots treballen conjuntament i la nota acostuma a ser millor, ja que el professorat normalment valora més positivament si la feina és elaborada en equip. També cal esmentar que alguns dels treballs són realitzats de manera no cooperativa, juxtaposant parts de la tasca de cada un dels membres, opció que s'accentua en la mesura que els augmenta la feina que han de lliurar.

Els estudiants són conscients que és important aconseguir formar un equip estable de companys a la universitat, que es correspon normalment amb el seu grup de referència, del qual agafen valors, normes i maneres de comportar-se. 
Aquestes relacions amb els grups provoquen un increment de la integració social i acadèmica de l'estudiant amb la universitat. La cerca d'un grup estable de companys també podria ajudar a entendre per què els alumnes de primer curs són els que obtenen els resultats pitjors i per què no s'aconsegueix disminuir el volum d'abandonaments a primer curs. Sembla que el fet de no gaudir encara d'un grup estable de companys i les dificultats d'adaptar-se a la universitat i al nou sistema hi podria incidir.

A continuació, s'hi presenten les citacions més representatives de les entrevistes realitzades als estudiants respecte a aquesta qüestió. En primer lloc, s'hi mosta una citació que esmenta els efectes beneficiosos del treball en grup i, en segon lloc, un alumne que explicita els problemes que tenen lloc quan un estudiant no aporta tota la feina que se li exigeix que faci.

Si hi ha problemes, es comenten en grup, perquè normalment et trobes tots els grups amb els mateixos problemes i, llavors, és clar, està molt bé, perquè tu quedes amb aquesta gent $\mathrm{i}$ com que, cada dos per tres, quedes amb ells perquè et toca, veus com funciona la gent i saps que, si jo necessito qualsevol cosa d'explicació en matemàtiques, no tinc problema, el proper dia que quedem els ho pregunto, segur que n'hi haurà un que m'ho sabrà explicar i viceversa. Saben que si necessiten qualsevol cosa d'informàtica, saben que si jo sóc allà, els ho explicaré en un moment, i això et treu un pes de sobre, a mi em treu pes de les assignatures. (Estudiant 27 d'Enginyeria Informàtica)

Si trobes un grup molt implicat, t'ho passes molt bé i treus molt bons resultats, però si et toca un grup malauradament amb una persona que ve a treure't tot el suc teu i ell a no fotre absolutament res, t'ho passes malament. (Estudiant 5 de Ciències Polítiques)

\section{Discussió de resultats}

Recuperant el triangle de necessitats a partir de $\mathrm{Maslow}^{8}$, veiem que els factors motivadors d'aprenentatge són la pertinença, l'autoestima i l'autorealització. Tal com s'ha mostrat a partir dels resultats, aquests tres aspectes s'han incentivat a patir de la implementació del pla pilot. Així, hi trobem: les relacions entre estudiants que fomenten la seva integració a la universitat (pertinença), l'increment de la retroacció amb els estudiants i l'augment dels aprovats i de les notes (autoestima), com també l'aprenentatge autònom independent i les accions d'aprenentatge profund (autorealització), en el benentès que la càrrega de feina no ho impedeixi.

La qüestió és que es realitza alhora una valoració negativa dels factors de manteniment en relació amb les necessitats bàsiques. Els estudiants es queixen del calendari a causa de l'acumulació de lliuraments de treballs en un mateix període de temps, dels horaris pels solapaments d'assignatures i la impossibilitat de compatibilitzar els estudis amb la feina, com també de dur a terme tots els treballs que se'ls demanen i assistir a classe.

8. Vegeu, a la figura 1, la jerarquia de les necessitats dels estudiants. 
Pel que fa a la seguretat, les queixes són reiterades per les estratègies d'avaluació dutes a terme pel professorat, per la falta de coordinació entre assignatures i pels escassos recursos d'informació, tant sobre el funcionament de les assignatures com sobre els objectius del pla pilot en general. S'hi complementen les aportacions d'alguns estudiants en relació amb la guia del professorat, ja que la reducció de classes ha comportat en alguns casos la sensació de no saber què han de fer.

A partir de les aportacions dels estudiants en relació amb el treball en grup i la importància d'establir un equip de treball que contribueixi alhora a integrar-los des del punt de vista acadèmic i social a la universitat, sembla que es produeixi una importància creixent de la necessitat de pertinença dels estudiants. Antigament, en una universitat on un estudiant podia matricular-se el primer dia i anar a l'examen sense gairebé trepitjar les classes, la necessitat de pertinença era un factor motivador de l'aprenentatge; en canvi, avui en dia, en què és necessari per als estudiants disposar de grups estables de companys per dur a terme la feina, es podria pensar que la necessitat de pertinença passa a ser, en gran part, un factor també de manteniment.

\section{Conclusions}

En general, es detecta una valoració negativa per part dels estudiants de la implementació dels plans pilot del Procés de Bolonya a les catorze titulacions analitzades de la UAB. En la majoria dels aspectes, les valoracions no arriben ni al llindar del suposat aprovat $i$, en alguns aspectes, les valoracions són realment molt baixes. En destaca, per exemple, el fet que la majoria dels estudiants considera que la informació ha estat escassa, i tan sols n'hi ha un 6\% que considera que ha esdevingut un procés participatiu. En relació amb la consideració de si la implementació s'està duent a terme de forma correcta per tres quartes parts dels estudiants, la valoració és negativa.

Alguns dels canvis docents que ha suposat la introducció dels plans pilot són valorats positivament pels estudiants quan se'ls planteja els objectius de manera teòrica, però comparteixen el fet de tenir la sensació que es tracta d'una aplicació no prou pensada i massa accelerada. Ho incentiva encara més la falta d'informació al professorat i la poca coordinació en moltes assignatures. En aquest sentit, destaquen les valoracions sobre l'avaluació continuada, consideren que és una manera millor d'avaluar els aprenentatges que l'examen final, però no creuen que comporti beneficis tal com s'està duent a terme, atès que hi ha un destacable augment del volum de feina.

Així, sembla que el Pla de Bolonya i els canvis de metodologia docent poden comportar efectes positius per a l'aprenentatge dels estudiants (pertinença, autoestima i autorealització), però fins que els aspectes recollits en els aspectes de manteniment no arribin a un cert llindar de qualitat, els factors motivadors no compensaran les mancances i els estudiants no veuran les possibles bondats del canvi metodològic que ha comportat aquest pla, amb la qual cosa augmentarà de manera clara l'aprenentatge profund (significatiu). 
Una altra de les aportacions importants de l'estudi és la visualització de les estratègies dels estudiants en relació amb els seus estudis. Així, aquests duen a terme accions diverses segons el tipus de tasca que els demana que realitzi el professor $\mathrm{i}$ intenten dur a terme tàctiques per reduir el volum de feina requerida. En aquest sentit, l'estudiant és un actor molt actiu en el procés d'aprenentatge $\mathrm{i}$ varia les seves accions segons el context en què es troba.

Finalment, sembla que la necessitat de pertinença, a partir de la introducció del Procés de Bolonya, en un context on cada vegada es demanen més treballs en grup, és cada vegada més un factor necessari per a l'aprenentatge dels estudiants universitaris, i no només un factor motivador.

\section{Referències bibliogràfiques}

AstiN, A. (1984). «Student involvement: A developmental theory for higher education». Journal of College Student Personnel, 25, 297-308.

Croll, P. (2004). «Families, social capital and educational outcomes». British Journal of Educational Studies, 52 (4), 390-416.

Elton, L. (1996). «Strategies to enhance Student Motivation». Studies in Higher Education, 21 (1), 57-67.

- (1988). «Student Motivation and Achievement». Studies in Higher Education, 13 (2), 215-221.

ETHINGTON, C.A. (2000). "Influences of the normative environment of peer groups on community college students' perceptions of growth and development». Research in Higher Education, 41 (6), 703-722.

HerzBerG, F. (1966) Work and the Nature of Man. Cleveland i Nova York: World Publishing Company.

Hu, S. i KuH, G.D. (2002). «Being (dis)engaged in educationally purposeful activities: The influences of student and institutional characteristics». Research in Higher Education, 43 (5), 555-575.

Botella, M. et al. (1997). Psicología Social. Barcelona: Edicions de la Universitat Oberta de Catalunya.

MASJUAN, J.M. (2004). «Convergencia europea, reformas universitarias, actitudes y prácticas de los estudiantes». Educar, 33, 59-76.

Masjuan, J.M.; Troiano, H. i Elias, M. (2009). «El contexto de enseñanza un elemento fundamental en la implementación de innovaciones pedagógicas relacionadas con los créditos europeos». Revista complutense de educación, 20 (2), 355-380.

MaSjuAn, J.M.; Troiano, H. i Elias, M. (2007). «Los factores de éxito de las universidades europeas en el proceso de incorporación al espacio europeo de educación superior y la experiencia de una universidad catalana». Educar, 40, 49-67.

MASJUAN, J.M. i TROIANO, H. (2009). «University students' success: A psycho-sociological approach». Higher Education, 58, 15-28.

MASJUAN, J.M. (2005). «Progresos en los aprendizajes, características de los estudios y motivaciones de los estudiantes». Papers: revista de sociología, 76, 97-133.

MERTON, R.K. (1964). Teoría y estructura social. Mèxic: FCE.

Prescott, A. i Simpson, E. (2004). «Effective student motivation commences with resolving "dissatisfiers"”. Journal of Further and Higher Education, 28 (3), 247-259. 
RUÉ, J. (2007). Enseñar en la universidad: El EEES como reto para la educación superior. Madrid: Narcea.

Tinto, V. (1998). "Colleges as Communities: Taking Research on Student Persistence Seriously». Review of Higher Education, 21 (2), 167-178.

- (2000). «Learning better together: The impact of learning communities on student sucess in higher education». Journal of Institutional Research, 9 (1), 48-53.

Troiano, H. (2005). "Consistencia y orientación del perfil profesional, percepción del mercado laboral y reacciones previstas ante posibles dificultades de inserción». Papers: revista de sociología, 76, 167-197.

Troiano, H.; Masjuan, J.M. i Elias, M. (2010). «La recontextualización de las políticas de incorporación al Espacio Europeo de Educación Superior: Un estudio de caso». Revista de Educación, 351, 283-310.

UNITAT D'AsSESSORAMENT PSICOPEDAGÖGIC (2007). Avaluació dels aprenentatges en el marc de l'EEES: Una aproximació a la perspectiva dels estudiants. Barcelona: UAP.

VILlAR Hoz, E. (2006). La construcción del capital social en las universidades. Girona: Documenta Universitaria.

Villar Hoz, E. i FONT, S. (2007). Guia del pla d'acció tutorial dels estudis de desenvolupament humà a la societat de la informació i psicologia. Girona: Documenta Universitaria.

VolKweIn, J.F.; KING, M.C. i Terenzini, P.T. (1986). «Student-Faculty relationships and intellectual growth among transfer students». The Journal of Higher Education, 7 (4), 413-430.

WeIDMAN, J.C. (1989). "The World of Higher Education: A Socialization-Theoretical Perspective». A: Hurrekmann, K. i Engel, U. (eds.). The Social World of Adolescents: International Perspectives. Berlín i Nova York: De Gruyter, 87-105. 